\title{
Oesophageal traction diverticulum resulting from pulmonary tuberculosis
}

\author{
Puja Gaur Khaitan, Thomas I Watson
}

Department of Surgery, Division of Thoracic and Esophageal Surgery, Georgetown University School of Medicine, Medstar Washington Hospital Center, Washington, DC, USA

\section{Correspondence to} Dr Puja Gaur Khaitan; puja.g.khaitan@medstar.net

Accepted 20 March 2020
Check for updates

(c) BMJ Publishing Group Limited 2020. No commercial re-use. See rights and permissions. Published by BMJ.

\footnotetext{
To cite: Khaitan $P G$,

Watson TJ. BMJ Case

Rep 2020;13:e234836.

doi:10.1136/bcr-2020-

234836
}

\section{DESCRIPTION}

A 56-year-old woman was referred with the primary complaints of bloating and abdominal burning. On prompting, she admitted to a long-standing history of reflux and constant feeling of fullness associated with a decreased appetite and 20-pound weight loss over the prior year. She denied halitosis, regurgitation of undigested food or dysphagia, but reported that she intermittently induced vomiting to relieve the bloating and fullness. A barium oesophagogram demonstrated a proximal oesophageal diverticulum at the level of aortic arch (figure 1A), which prompted a surgical referral. A gastric emptying study was normal. A flexible upper endoscopy confirmed a large proximal oesophageal diverticulum with a broad neck and without retained food (figure 1B). No other pathology was observed, and she tested negative for Helicobacter pylori. As all these tests did not explain her symptomatology, a CT of the chest, abdomen and pelvis was obtained. It demonstrated right upper lobe pulmonary fibrosis and a contrast-filled diverticulum of the proximal thoracic oesophagus (figure 1C). On further prompting, the patient admitted to having undergone treatment for tuberculosis over 10 years ago in Mexico, explaining her lobar fibrosis. As her symptoms were not attributable to the diverticulum, she underwent an evaluation of gastrooesophageal reflux. A 48-hour Bravo oesophageal $\mathrm{pH}$ study performed on acid suppression therapy showed a DeMeester score of 2.3, suggesting that the medications were controlling her oesophageal
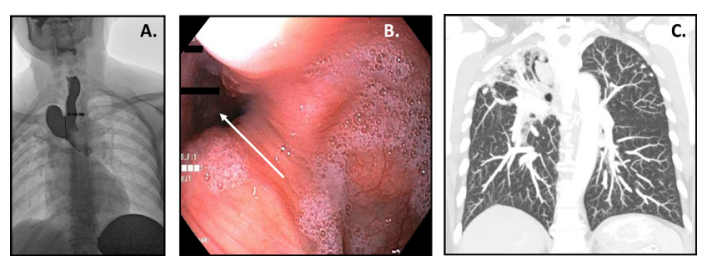

Figure 1 (A) Barium oesophagram. (B) Endoscopic view of the diverticulum. (C) Follow-up CT of the chest.

\section{Patient's perspective}

I want to share my story with others. If I can help another patient get diagnosed and managed appropriately (the way I did), I will feel rewarded.

\section{Learning points}

- Recognise the features of a traction versus pulsion diverticulum.

- Recognise the inconsistencies in a patient's symptomatology and the workup/test results. If things do not add up, make sure that you have thoroughly worked the patient up.

- Treat the patient, not the numbers or the images.

acid exposure. A simultaneous manometry was unremarkable. She was diagnosed with functional dyspepsia, proton pump inhibitor therapy was optimised and sucralfate was added to her medical regimen. Six months later, her symptoms had resolved, and she had gained 20 pounds. No intervention was undertaken relative to the diverticulum, thus suggesting that her symptoms were secondary from reflux not warranting a diverticulectomy.

Contributors PGK: helped with conception and design, acquisition of data or analysis and interpretation of data; agreement to be accountable for the article and to ensure that all questions regarding the accuracy or integrity of the article are investigated and resolved. PGK, TJW: drafting the article or revising it critically for important intellectual content; final approval of the version published.

Funding The authors have not declared a specific grant for this research from any funding agency in the public, commercial or not-for-profit sectors.

Competing interests None declared.

Patient consent for publication Obtained.

Provenance and peer review Not commissioned; externally peer reviewed. 
Copyright 2020 BMJ Publishing Group. All rights reserved. For permission to reuse any of this content visit https://www.bmj.com/company/products-services/rights-and-licensing/permissions/

BMJ Case Report Fellows may re-use this article for personal use and teaching without any further permission.

Become a Fellow of BMJ Case Reports today and you can:

- Submit as many cases as you like

Enjoy fast sympathetic peer review and rapid publication of accepted articles

Access all the published articles

Re-use any of the published material for personal use and teaching without further permission

Customer Service

If you have any further queries about your subscription, please contact our customer services team on +44 (0) 2071111105 or via email at support@bmj.com.

Visit casereports.bmj.com for more articles like this and to become a Fellow 